NBER WORKING PAPER SERIES

DID THE NEW DEAL SOLIDIFY THE 1932 DEMOCRATIC REALIGNMENT?

\author{
Shawn Kantor \\ Price V. Fishback \\ John Joseph Wallis \\ Working Paper 18500 \\ http://www.nber.org/papers/w18500
}
NATIONAL BUREAU OF ECONOMIC RESEARCH
1050 Massachusetts Avenue
Cambridge, MA 02138
November 2012

Fishback's and Kantor's work on the New Deal has been supported by National Science Foundation Grants SBR-9708098, SES-0080324, SES-0214395, SES-0617942, SES-0617972, and SES- 0921732. We are solely responsible for the views expressed in the article. The views expressed herein are those of the authors and do not necessarily reflect the views of the National Bureau of Economic Research.

NBER working papers are circulated for discussion and comment purposes. They have not been peerreviewed or been subject to the review by the NBER Board of Directors that accompanies official NBER publications.

(C) 2012 by Shawn Kantor, Price V. Fishback, and John Joseph Wallis. All rights reserved. Short sections of text, not to exceed two paragraphs, may be quoted without explicit permission provided that full credit, including $(\mathrm{C}$ notice, is given to the source. 
Did the New Deal Solidify the 1932 Democratic Realignment?

Shawn Kantor, Price V. Fishback, and John Joseph Wallis

NBER Working Paper No. 18500

November 2012

JEL No. H5,N42

\begin{abstract}
$\underline{\text { ABSTRACT }}$
The critical election of 1932 represented a turning point in the future electoral successes of the Democrats and Republicans for over three decades. This paper seeks to measure the importance of the New Deal in facilitating the Democrats' control of the federal government well into the 1960s. We test whether long-differences in the county-level electoral support for Democratic presidential candidates after the 1930s can be attributed to New Deal interventions into local economies. We also investigate more narrowly whether voters rewarded Roosevelt from 1932 to 1936 and from 1936 to 1940 for his efforts to stimulate depressed local economies. Our instrumental variables estimates indicate that increasing a county's per capita New Deal relief and public works spending from nothing to the sample mean (\$277) would have increased the long-run support for the Democratic party by 10 percentage points. We further find that the long-run shift toward the Democratic party after 1928 was not a function of the Roosevelt landslide victory in 1932. Roosevelt's ability to win over voters during the 1936 and 1940 elections, however, did matter for the long-term.
\end{abstract}

Shawn Kantor

School of Social Sciences, Humanities and Arts Department of Economics

University of California, Merced

5200 N. Lake Road

Merced, CA 95343

and NBER

skantor@ucmerced.edu

Price V. Fishback

Department of Economics

University of Arizona

Tucson, AZ 85721

and NBER

pfishback@eller.arizona.edu
John Joseph Wallis

University of Maryland

College Park, MD 20742

and NBER

wallis@econ.umd.edu 


\title{
Did the New Deal Solidify the 1932 Democratic Realignment?
}

\author{
Shawn Kantor, University of California, Merced and NBER \\ Price V. Fishback, University of Arizona and NBER \\ John Joseph Wallis, University of Maryland and NBER
}

\begin{abstract}
When I took office, the first thing we had to do was mount an aggressive response to the worst economic crisis we'd seen since the Great Depression, because we didn't want a second Great Depression ... And by the way, one of those steps was called the Recovery Act. And I want everybody to understand here's what it did . . . Now, sometimes you've got people who were critics of what we did, but they'll show up at the ribbon cutting. So I just want to make clear here what we did, because people try to score political points by attacking the Recovery Act, that's what they're attacking . . . relief for laid-off workers, investment in your community - 2.5 million Americans went to work today who otherwise wouldn't have gone to work.

- President Barack Obama, "Remarks by the President at Ottumwa, Iowa Town Hall," April 27, 2010 (http://www.whitehouse.gov/the-press-office/remarks-presidentottumwa-iowa-town-hall)
\end{abstract}

\section{Introduction}

The election of 1932 was a turning point in the fortunes of the Democrats and

Republicans. Democrats had won just three of the previous ten presidential elections and had held a majority in both the House and the Senate in only four of the previous 20 sessions of

Congress. After the "critical election" of 1932, Democrats won seven of the ten presidential elections from 1932 to 1968 and majorities in both the House and the Senate in all but two of the 19 Congressional elections. The New Deal, of course, was not foreshadowed in Roosevelt's 1932 campaign, and could not be the cause of the 1932 election results. Hoover and the Republicans lost that election more than the Democrats won it. But there was nothing inevitable about the Democrats' becoming the majority party for the next fifty years, they could have squandered the opportunity handed to them by the nation's deepest depression, but they did not. 
This paper seeks to measure the importance of the New Deal in facilitating the Democrats' control of the federal government well into the 1960s. From July 1933 to June 1941 (from fiscal year 1934 to fiscal year 1941), the federal government spent over \$27 billion on programs cooperatively administered by state and local governments aimed at relieving the unemployed, building the nation's infrastructure, and supporting farmers' incomes, among other programs. Total federal government expenditures in fiscal year 1929 amounted to only $\$ 3.2$ billion, so the New Deal spent more each year on programs administered in conjunction with state and local governments than the federal government spent in total prior to the onset of the Depression. Our aim is to estimate the impact of that spending on electoral outcomes over the course of the 1930s and on long-run changes in electoral support into the 1960s. This analysis will not tell us why the Democrats became the majority party in the middle of the $20^{\text {th }}$ century, but it will help us to understand the role that an expanding federal government may have played in securing that majority.

The Roosevelt administration funded a variety of different programs in an attempt to revive economic activity. The Public Works Administration (PWA) handed out grants to build civil infrastructure, while the Federal Emergency Relief Administration (FERA), the Civil Works Administration (CWA), and the Works Progress Administration (WPA) granted state and local governments funds to provide work relief and direct relief and to build and maintain infrastructure. The New Deal launched the farm programs that paid farmers to alter their land usage. New Deal agencies loaned funds to state and local governments, banks, homeowners, farmers, and to industry in order to provide needed liquidity. Through the Federal Housing Administration (FHA) the federal government sought to prop up the housing sector by insuring home improvement and mortgage loans. 
Not all states or counties fared equally in terms of federal support. There was substantial geographic variation in how New Deal grants were distributed and there were great differences in the recoveries of local economies during the course of the New Deal. We have constructed measures of annual federal spending in over 3,000 counties from 1933 to 1939 . We focus on two sets of grants programs that potentially directly impacted local citizens' economic wellbeing: relief and public works spending and Agricultural Adjustment Administration (AAA) spending. Relief and public works spending was used to provide employment by hiring people to build public works projects or to perform public maintenance activities. In contrast, the AAA grant payments were specifically designed to pay farmers to take land out of production in an attempt to curtail supply so that prices, and consequently farmers' incomes, would rise. The AAA potentially had perverse economic and political effects because when farmers were encouraged to reduce acreage, the demand for labor fell, and farm workers were disadvantaged. Fishback, Horrace, and Kantor (2005 and 2006) have shown that greater AAA spending in a county caused retail sales to decline and encouraged greater out-migration.

We test whether long-differences in the county-level electoral support for Democratic presidential candidates after the 1930 s can be attributed to these New Deal interventions into local economies. We also investigate more narrowly whether voters rewarded Roosevelt from 1932 to 1936 and from 1936 to 1940 for his efforts to stimulate depressed local economies. Our working hypothesis, based on fundamental principles in both the political economy and political science literatures, is that local voters should have rewarded the president's efforts to help their economies emerge from the Great Depression, all else constant. The predicted impact of AAA spending is more uncertain, however, and remains an empirical question, as the economic benefits of AAA spending were unequally distributed across various segments of the farm 
population. In the process of estimating the contemporaneous electoral impact of local New Deal spending, we must be cognizant of the potential for endogeneity that would tend to bias an OLS estimate downward. ${ }^{1}$ First, if Democrats allocated New Deal funds strategically towards places where support for the President or the Democrats was marginal or tenuous, then New Deal spending might appear to lower Democratic support. Second, if we are unable to fully measure economic shocks at the county level, we might omit a variable, such as a negative economic event, that triggered greater New Deal spending but also placed blame on the Democrats. In both of these cases, an OLS coefficient would be biased downward and we would underestimate the true effect of New Deal spending on Roosevelt's local electoral support. Therefore, we adopt an instrumental variables approach to isolate the causal role of New Deal spending on Roosevelt's electoral outcomes.

One seeming benefit of examining the long-term effect of New Deal spending is that the allocation decisions in the 1930s might be considered exogenous to voting decisions decades later. Because voting behavior is serially correlated, however, the worry about endogeneity bias is still relevant even when thinking about voting outcomes over a long time horizon. In fact, controlling for this bias is critical to understanding the causal effect of the New Deal on the electoral success of the Democratic party. To preview the results, our instrumental variables estimates indicate that increasing a county's per capita New Deal relief and public works spending from nothing to the sample mean (\$277) would have increased the long-run support for the Democratic party by 10 percentage points. This effect holds even when we control for marginal changes in Roosevelt's electoral support over the course of the New Deal period. We further find that the long-run shift toward the Democratic party after 1928 was not a function of

\footnotetext{
${ }^{1}$ See Levitt and Snyder (1997) for a discussion of the endogeneity bias in early studies to identify the political impact of government spending.
} 
the Roosevelt landslide victory in 1932. That is, the change in the Democratic share of the vote between 1928 and 1932 does not explain much of the overall long-run shift toward the Democrats from the period prior to the 1932 critical election into the 1950 s. On the other hand, Roosevelt's ability to win over voters during the 1936 and 1940 elections did matter for the longterm. The shift in the Democratic share of the presidential vote between 1932 and 1936 and between 1936 and 1940 is statistically significantly related to the long-run success of the Democrats. While the voters the Democrats gained in the 1932 election reflected Hoover's failure and indeed could have been ephemeral, the votes gained in the 1936 and 1940 elections reflected the political benefits of the New Deal and those effects persisted well into the 1960s. Our detailed empirical analysis of the 1936 and 1940 elections shows the importance of New Deal spending on relief and public works to Roosevelt's electoral successes, especially in 1936.

\section{Geographic Variation in the Great Depression and the New Deal Response}

The 1930s was a decade of lost output for the U.S. economy. By 1933 both real per capita GDP and per capita retail sales had fallen to approximately two-thirds of their 1929 peaks. In per capita terms, real retail sales returned to its pre-Depression level by 1939, while real GDP did not return to its 1929 level until $1940 .^{2}$

Gauging economic performance at the local level during the 1930s is complicated because modern indices of local economic activity, such as unemployment rates and personal income, were unavailable. As an alternative, retail sales, which were reported for every county in the U.S. in 1929, 1933, 1935, and 1939, is a credible measure of local economic activity. The ratio of 1939 retail sales to 1929 retail sales at the state level ranged from a low of 77 percent in Mississippi to a high of nearly 125 percent in South Carolina. The New England states appear to

${ }^{2}$ See series T81 deflated by series E135 and series F4 in U.S. Bureau of the Census (1975, pp. 210-11, 224, and 843). See also Romer (1992). 
have had the most success in recovering to their pre-Depression levels as every state had higher real retail sales in 1939 than in 1929. Within many states there was substantially more variation than there was across the states. Texas counties experienced some of the greatest variation as the discovery of new oil fields led to an explosion of economic activity in some counties, while the Dust Bowl and its aftermath contributed to a continuation of the Depression in some agricultural counties. $^{3}$

The crisis of the Great Depression led the Roosevelt administration to distribute unprecedented amounts of federal money in the form of nonrepayable grants. The federal government distributed $\$ 16.5$ billion in grants from 1933 to 1939. The grants represented a new role for the federal government during peacetime, as the New Deal increased the federal government's outlays as a share of GDP from about four to eight percent. Furthermore, the federal government began spending large amounts of money where it had spent very little before, setting the stage for a long-term structural shift in the financial responsibilities of the national, state, and local governments. ${ }^{4}$ As a share of government expenditures at all levels, the New Deal raised the proportion of federal spending from 30 percent in 1932 to 46 percent by 1940 (Wallis 1984, pp. 141-42).

${ }^{3}$ See Fishback, Horrace, and Kantor (2005, Table 1) for a detailed statistical description of the distribution of retail sales performance at the state and county level.

${ }^{4}$ Our measure of New Deal spending does not encompass all federal spending, so our analysis does not address the impact of all forms of federal expenditures. It should be noted, however, that much of the New Deal represented an entirely new role for the federal government. For example, agricultural spending, relief spending, many forms of lending to state and local governments, and insurance of mortgage loans broke new ground for the federal government. In addition, there were major increases in federal spending from the early 1930s on roads, public buildings, public works, and conservation. The New Deal programs caused federal intergovernmental and direct outlays on education to rise from 26 million in 1932 to 235 million in 1934, on highways from 217 million to 599 million, on public welfare and employment security from 2 million to 585 million, on housing and urban renewal from 0 in 1932 to 3 million in 1934 to 71 in 1936. Spending on the primary tasks of the federal government prior to the 1930s generally did not display the same marked jumps. See Wallis (1985) and U.S. Bureau of Census (1975, pp. 1124-26). 
In 1940 the U.S. Office of Government Reports (OGR) produced county-level statistics on federal spending on over 30 New Deal programs for the period March 3, 1933, through July 30, 1939. We divide the New Deal grants into two distinct categories that potentially had quite different impacts on local economies: public works and relief grants; and Agricultural Adjustment Administration benefits paid to farmers. ${ }^{5}$ We group public works and relief grants together because the programs had broadly similar goals of hiring workers to build various public works projects and to provide other public services. Relief grants were primarily distributed under the aegis of the Works Progress Administration (WPA), the Federal Emergency Relief Administration (FERA), the Civil Works Administration (CWA), the Social Security Administration's Aid to the Blind, Aid to Dependent Children, and Old-Age Assistance, and the Farm Security Administration's “rural rehabilitation" programs. The principal goal of these programs was to provide immediate relief to the unemployed and low-income people, as 85 percent of the grants were used to hire the unemployed on work relief jobs. These relief jobs ranged from make-work activities to maintenance activities to the building of sidewalks, post offices, schools, local roads, and other additions to local infrastructure. The public works grants included expenditures by the Public Works Administration (PWA), Public Buildings Administration (PBA), and the Public Roads Administration (PRA). These grants were also

\footnotetext{
${ }^{5}$ The U. S. Office of Government Reports, "County Reports," also provided information on $\$ 10.4$ billion in repayable loans under a variety of programs as well as data on the Federal Housing Administration's insurance of $\$ 2.7$ billion in mortgage loans. We do not focus attention on these programs for several reasons. First, the nature of the loans and insurance were substantially different from the nonrepayable grants and it is hard to determine the true dollar size of the benefits that the counties received. Second, in the analysis we seek to reduce problems of endogeneity by using instrumental variables. We face difficulties in finding enough effective instruments that will allow us to simultaneously identify more than two or three New Deal variables in a system of equations. Third, by omitting the loans and FHA insurance we reduce measurement error at the risk of increasing omitted variables bias in our estimates of the impact of New Deal grants. We do not believe that the bias will be large from omitting the loans and FHA insured loans because these variables are largely orthogonal to the grants variables.
} 
used largely to employ workers, but the programs were administered differently as they focused less on hiring people from the relief rolls and, thus, were able to employ a broader class of skilled workers. The public works programs also focused more on building large-scale projects like dams, roads, schools, sanitation facilities, and other forms of civil infrastructure. ${ }^{6}$

The federal New Deal expenditures that provided the primary aid to the farm sector came through the AAA's payments to farmers to remove land from production. The impact of the AAA grants on local economic outcomes was likely smaller than the impact of the relief grants and potentially even negative. On the one hand, farm owners might have received higher net incomes from the AAA program. Payments typically exceeded the income farmers would have earned on the land that they took out of production because the least productive land was removed first. If the AAA succeeded in raising farm prices, the farmers also would have earned more on the crops they produced. In addition, the higher prices and the limits on land usage would have encouraged farmers to raise yields on the land they kept under cultivation. On the other hand, the AAA had an adverse effect on the incomes of farm laborers, tenants, and sharecroppers. There is evidence that sharecroppers and tenants did not receive their full share of the AAA payments on the lands that they had cultivated and that some were demoted to wage laborers. ${ }^{7}$ Further, the AAA payments required that the farmer remove land from production. Consequently, the demand for farm labor likely fell, leading to declines in laborers' incomes. ${ }^{8}$ Previous research has shown that the net effect of the AAA was in fact negative as greater AAA spending in a county led to diminished retail sales and out-migration. ${ }^{9}$

\footnotetext{
${ }^{6}$ See Clarke (1996, pp. 62-68) and Schlesinger (1958, pp. 263-96).

${ }^{7}$ See Depew, Fishback, and Rhode (2012), Biles (1994, pp. 39-43), Whatley (1983), and Saloutos (1974).

${ }^{8}$ See Alston (1981).

${ }^{9}$ See Fishback, Horrace, and Kantor $(2005,2006)$.
} 
As was the case with the recovery in retail sales, there was substantial variation in the extent of per capita New Deal spending across the country. The patterns of New Deal spending across states and within states differed for the two broad categories. Spending on relief and public works was over $\$ 125$ per person in the heavily urbanized states in the Northeast and Midwest and was well over $\$ 200$ per person in many western states. Meanwhile, relief and public works expenditures were below $\$ 80$ per person in many southern states. AAA expenditures were highest in agricultural regions, particularly the West North Central region and the Mountain West. The South received substantially higher amounts per capita than did the Northeast, but much less than the amounts spent in the West and the West North Central.

\section{Estimating the Impact of the New Deal of Electoral Outcomes}

Our first goal is to measure whether changes in Democratic voting during the New Deal and New Deal spending had long-term consequences for the success of the Democratic Party at the county level after the "critical election" of 1932. To test this idea, we regress the longdifference between the share of votes for Democratic presidential candidates averaged over 1952, 1956, and $1960\left(\bar{V}_{i, 1952-1960}\right)$ and the average share of votes for Democratic candidates

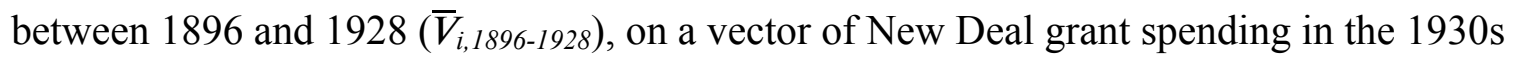

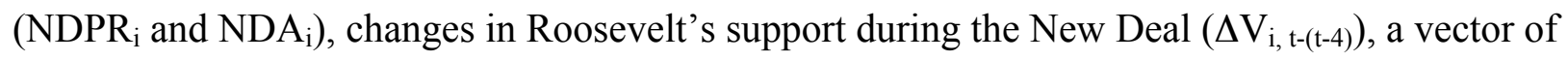
structural socioeconomic variables $\left(\mathrm{X}_{i, 1930}\right)$, and state fixed effects $(\mathrm{S})$. The analysis is conducted at the county level (subscript $i$ ). Specifically, we estimate the following equation:

$$
\bar{V}_{i, 1952-1960-} \bar{V}_{i, 1896-1928}=\beta_{1} \Delta \mathrm{V}_{\mathrm{i}, \mathrm{t}-(\mathrm{t}-4)}+\beta_{2} \mathrm{NDPR}_{\mathrm{i}}+\beta_{3} \mathrm{NDA}_{\mathrm{i}}+\beta_{4} \mathrm{X}_{i, 1930}+\beta_{5} \mathrm{~S}+\varepsilon_{\mathrm{i}}(1)
$$

where $\varepsilon_{\mathrm{i}}$ is the error term. 
Even in the context of a long-difference estimation, because voting patterns are serially correlated, endogeneity of the New Deal variables may be a concern. That is, to the extent that Roosevelt targeted New Deal funds to places where Democratic support was tenuous, then an OLS estimate of the New Deal's effect on voting would be biased downward. Therefore, we also estimate a 2SLS model in which the first-stage equations are:

$$
\begin{aligned}
& \mathrm{NDPR}_{\mathrm{i}}=\theta_{1} \mathrm{INST}_{\mathrm{i}}+\theta_{2} \Delta \mathrm{V}_{\mathrm{i}, \mathrm{t}-\mathrm{t}(\mathrm{t}-4)}+\theta_{3} \mathrm{X}_{i, 1930}+\theta_{4} \mathrm{~S}+v_{\mathrm{i}} \\
& \mathrm{NDA}_{\mathrm{i}}=\gamma_{1} \mathrm{INST}_{\mathrm{i}}+\gamma_{2} \Delta \mathrm{V}_{\mathrm{i}, \mathrm{t}-\mathrm{t}-\mathrm{t}-4)}+\gamma_{3} \mathrm{X}_{i, 1930}+\gamma_{4} \mathrm{~S}+\xi_{\mathrm{i}}
\end{aligned}
$$

where INST $\mathrm{i}$ is a vector of instrumental variables that were selected because they are correlated with the New Deal grants, but uncorrelated with the error term, $\varepsilon_{\mathrm{i}}$, of the vote equation. The error terms in the equations, $\varepsilon_{\mathrm{i}}, v_{\mathrm{i}}$, and $\xi_{\mathrm{i}}$, are assumed to be independent and identically distributed and uncorrelated with each other.

We chose 1960 as the terminal year because political scientists debate whether 1964 or 1968 were critical elections themselves. $\Delta \mathrm{V}_{\mathrm{i}, \mathrm{t}-\mathrm{t}(\mathrm{t}-4)}$ is a vector of three variables measuring the change in Roosevelt's share of the popular vote in county $i$ in election year $t(1932,1936$, and 1940) relative to the Democratic vote share in the prior election. We include these variables to determine whether and when Roosevelt was instrumental in the short-term in shifting long-term voter sentiment toward the Democratic Party. The shift in the vote between 1928 and 1932 reflected Hoover's failure rather than Roosevelt's policies, while the shifts in votes between 1932 and 1936, and 1936 and 1940, reflect two different regimes under Roosevelt. If Roosevelt's policies, even beyond New Deal spending that we measure directly, really mattered for long-run Democratic success, we would expect to see the 1936 and 1940 vote shifts play an important role. 
We include state dummy variables to capture unmeasured factors that were common to the counties in the states but varied across states. The state dummy variables might capture state policies and changes in state policies over time, differences in the cost of living across states, policies related to state taxation and spending, or differences in state political organization, strategy, or effort. One example of a major policy change during the 1930s for which the state dummies would control is the introduction of income taxes and sales taxes in certain states. We also cluster the standard errors at the state level to account for the fact that presidential politics centers on winning majorities within a specific state, not county, so political strategy across counties within a state were likely correlated.

$\mathrm{NDPR}_{\mathrm{i}}$ is real per capita New Deal public works and relief spending in county $i$ from March 1933 to December 1939, and $\mathrm{NDA}_{\mathrm{i}}$ is real per capita New Deal AAA grants over the same period. New Deal funds were not distributed randomly. In fact, there is evidence that they were distributed at least in part in response to economic crises across the country. As a result, there is the possibility that OLS New Deal coefficients will be biased if such crises were correlated with voters' decisions to vote for Roosevelt, especially if we cannot fully control for those differences. Moreover, Democrats may have targeted spending in certain areas where the party faced greater political challenges, which would also impart a negative bias to an OLS coefficient of New Deal spending. New Deal administrators stated that their objectives in distributing relief funds and, to some extent, the public works funds were to provide jobs for the unemployed, to offset economic distress, and to promote economic recovery. The explicit goal of the AAA program was to raise farmers' incomes, although landowners in particular tended to be the disproportionate beneficiaries. The empirical literature on the geographic distribution of programmatic New Deal spending at the county level suggests that relief spending was 
distributed to areas where there was relatively more economic distress, while the public works programs responded to higher unemployment. ${ }^{10}$

The instrumental variables procedure requires that we find variables that were correlated with New Deal spending but uncorrelated with the error term of vote equation (1). We use four criteria in choosing appropriate instruments. First, the instrumental variables have to be important determinants of New Deal spending and not themselves influenced by the New Deal. The instruments we choose are from a time period prior to the New Deal or are geographic characteristics of the county so the New Deal could not have influenced the variables, nor could voting in the 1930 s or after have affected the instruments. Second, the instruments had to provide statistical explanatory power to at least one of the first-stage New Deal regressions. The statistical relevance of a variable was determined using a t-test of its coefficient, and F-tests to determine the joint statistical significance of the group of variables. Third, the instrument's coefficient had to have the expected sign in at least one of the first-stage regressions. We expect the instruments to make economic sense in the first-stage regression so that the second-stage results do not rely on spurious relationships from the first-stage estimation. Fourth, there should be no reason to expect that the instruments themselves should be included as a correlate in the second-stage voting equation.

A number of scholars have used natural resource endowments or physical characteristics as instruments in cross-sectional analyses in part because these factors were established long before the decisions under consideration in the research were made (see, e.g., Frankel and Romer 1999; Hoxby 2000). The presence of a major river in a county, for example, likely influenced public works and relief spending because the potential for flooding and the requirements for

${ }^{10}$ See Fishback, Kantor, and Wallis (2003). 
dredging and docks and other public services along the river provided local officials with readymade projects that they could propose to federal New Deal administrators. ${ }^{11}$ More major rivers in a county meant more public works opportunities. In the case of agriculture, rivers were likely to influence the types of crops chosen and, hence, the pattern of AAA spending.

To create a useful instrument, we looked beyond the mere presence of a river because every county in the United States has at least one river, and often many more, within its boundaries. Therefore, we sought to create an instrument that describes each county's access to "major" rivers because the size of dredging and port projects was likely to increase as the rivers increase in size. In prior research, we have experimented with three definitions of "major" rivers. Our first definition of a major river is one that passes through 50 or more counties, which includes only the Ohio, Mississippi, and Missouri Rivers. For this category, the variable records the number of these three major rivers that passed through the county. The second variable measures the number of rivers in the county that pass through 21 to 50 total counties and the third variable measures the number of rivers in the county that pass through 11 to 20 total counties. The three groupings captured nearly all of the major rivers in the U.S. ${ }^{12}$ While these variables have proven effective in prior research, the parameterization that proved most powerful in this context was a single variable measuring access to rivers that ran through 21 or more

${ }^{11}$ As one example, Hoxby (2000) used the number of streams in an area as an instrument for the number of school districts on the grounds that they were natural boundaries that would have influenced the location of school district boundaries. As seen in the text, we use major rivers for different reasons.

${ }^{12}$ In 1,763 counties the value for each major river variable was zero. The maximum number of major rivers within a county was two for the rivers passing through 11 to 20 total counties, three for the rivers passing through 21 to 50 total counties, and 2 for the largest rivers. Summing the total major rivers across all three categories, the maximum in any one county was 4 . We control for the possibility that bigger counties would have had more rivers by including county land area in the analysis. We also experimented with a variable measuring the number of rivers in a county passing through 5 to 10 total counties, but the coefficients in the first-stage regressions were always small and statistically insignificant. 
counties. Adding the separate variables did not change the second-stage results appreciably, but reduced the power of the first-stage instruments, so we have chosen to use only the 21 -or-morecounty measure. ${ }^{13}$

Could the rivers, however, have influenced voting decisions? Certainly, rivers influence the location of cities, farming decisions, and economic activity, which, in turn, may have influenced how people voted. However, many of the avenues by which the presence of rivers would have influenced such voting - economic activity, urbanization, farm structure, state fixed effects, homeownership - are controlled in the second-stage vote equation. Thus, for the river variable to be an unsuitable instrument, it would have to have an additional influence on the voting equation error term above and beyond these other control factors.

In their analysis of the determinants of 18 New Deal programs, Fishback, Kantor, and Wallis (2003) found that the elasticity of per capita AAA spending with respect to average farm size in 1929 was larger than nearly every other elasticity among all the programs. Voting in the 1930s and after obviously could not have influenced average farm size in 1929, but we need to consider whether average farm size belongs in the voting equation or whether it might be correlated with unobservables in the equation. At first blush it would seem that farm scale could have influenced the course of agricultural development during the 1930s and, thus, could have influenced how people voted later. However, the likely mechanism through which farm size would have influenced voting is through income opportunities. But income opportunities have largely been controlled in the regression with the inclusion of retail sales per capita, farm

\footnotetext{
${ }^{13}$ We have experimented with other geography variables, in addition to access to major rivers, but they proved not to have much explanatory power in the first stage in this setting. We tried such instruments as the range in elevation within the county, the maximum elevation, access to coastlines along the Atlantic Ocean, Pacific Ocean, Gulf Coast, and the Great Lakes, the presence of bays, lakes, swamps, and beaches, and various measures of soil quality. In all of these experiments river access and average farm size in 1929 (discussed below) provided the most power in the first-stage estimation.
} 
ownership, the share of the county's land devoted to agriculture, and a dummy variable measuring whether the county experienced the Dust Bowl during the 1930s (see Hanson and Libecap 2004).

The results from the first-stage equations indicate the strength of the identifying instruments for the public works and relief regression and the AAA regression. The specific ttests for individual instruments (not shown) in the first-stage public works and relief regression show that the presence of large rivers led to statistically significantly higher New Deal spending, as expected, while average farm size had no impact on relief and public works spending. Similarly, the t-tests for the individual instruments (not shown) in the first-stage AAA regression show that average farm size was strongly positively associated with more AAA spending in a county, while access to larger rivers had little effect. The F-tests shown in the tables below strongly reject the hypothesis that the coefficients of the two instruments were simultaneously equal to zero in the two first-stage regressions at the 1 percent level. While the F-statistics often are greater than 10, a standard benchmark for determining the risk of bias from weak instruments, there are occasions when the statistic fall below. Generally, the instruments perform less well as we add more correlates to the equations.

The second idea we examine is whether the New Deal had a short-term impact on Roosevelt's electoral outcomes at the county level in both 1936 and 1940. As noted above, the analysis is complicated by the fact that the endogeneity of New Deal grant spending will likely bias an OLS estimate downward. Therefore, we seek to reduce the endogeneity bias of the New Deal variables' impacts by estimating the following set of equations:

$$
\mathrm{V}_{\mathrm{it}}=\varphi_{1} \mathrm{NDPR}_{\mathrm{it}-4 \text { to t }}+\varphi_{2} \mathrm{NDA}_{\mathrm{it}-4 \text { to t }}+\varphi_{3} \mathrm{~V}_{\mathrm{i}, 1932}+\varphi_{4} \mathrm{E}_{\mathrm{it}-4 \text { to t }}+\varphi_{5} \mathrm{X}_{i, 1930}+\varphi_{6} \mathrm{~S}+\eta_{\mathrm{i}}
$$




$$
\begin{aligned}
& \mathrm{NDPR}_{\mathrm{it} \text {-4 to t }}=\lambda_{1} \mathrm{INST}_{\mathrm{i}}+\lambda_{2} \mathrm{~V}_{\mathrm{i}, 1932}+\lambda_{3} \mathrm{X}_{i, 1930}+\lambda_{4} \mathrm{~S}+\kappa_{\mathrm{i}} \\
& \mathrm{NDA}_{\mathrm{it}-4 \text { to t }}=\tau_{1} \mathrm{INST}_{\mathrm{i}}+\tau_{2} \mathrm{~V}_{\mathrm{i}, 1932}+\tau_{3} \mathrm{X}_{i, 1930}+\tau_{4} \mathrm{~S}+\mu_{\mathrm{i}}
\end{aligned}
$$

where $\mathrm{V}_{\mathrm{it}}$ is the percent of the vote for Roosevelt in each county $i$ in year $t$ (either 1936 or 1940), $\mathrm{NDPR}_{\mathrm{i} \text { t-4 to }}$ is real per capita New Deal public works and relief grants during the four year period leading up to the election (specifically, March 1933 through December 1936 and January 1937 to December 1939) and NDA $_{i}$ t-4 to $t$ is real per capita New Deal AAA grants over the same periods. ${ }^{14} \mathrm{~V}_{\mathrm{i}}$ is a measure of prior voting behavior in county $i$, specifically Roosevelt's vote share in 1932, before the New Deal activity began. Including the 1932 vote effectively makes our estimation equation a quasi-first difference estimation. $E_{i t-4 \text { to } t}$ is a vector of variables measuring economic factors at the time of the election or that occurred since the last election that might have influenced voters' decisions in county $i$, such as changes in retail spending (a proxy for changes in income), unusual bouts of wetness, drought, temperature, or whether the county experienced Dust Bowl conditions. $\mathrm{X}_{i, 1930}$ is a vector of structural correlates, measured in 1930, that might have determined how various interest groups aligned politically; $\mathrm{S}$ is a vector of state dummy variables; and INST $_{i}$ is the vector of instrumental variables discussed above. The error terms of the equations are all assumed to be independent and identically distributed and uncorrelated with each other.

14 The Office of Government Reports (1939) reported county information for the period March 1933 to June 1939. The Office also reported state level information for each fiscal year for the public works, relief, and agricultural grants. We split the county-level spending into annual fiscal year estimates by using that fiscal year's share of the state totals for the period March 1933 to June 1939. We then created calendar year estimates by taking the average of the fiscal years. For example, the calendar year estimate from January 1 to December 31, 1936 is one half of the estimate for the fiscal year from July 1, 1935, to June 30, 1936, plus one half of the estimate for the fiscal year from July 1, 1936, to June 30, 1937. For the calendar year 1939 the estimate is equivalent to the fiscal year estimate from July 1, 1938, to June 30, 1939. 


\section{Long-Term Results}

In order to estimate the effect of the New Deal on the long-term electoral support for the Democrats from the pre- to post-New Deal era, we calculated the difference in the Democratic share of the presidential vote from 1952 to 1960 and subtracted the Democratic share of the vote from the elections of 1896 to 1928 . The regression results estimating equations (1)-(3) are presented in Table 1. The OLS regression specification in Column (1) includes only the New Deal variables and state fixed effects; specification (2) is a 2SLS estimation with the same variables; column (3) only includes the marginal vote changes during the 1930s and state fixed effects; specifications (4) and (5) include both sets of variables in an OLS and 2SLS setting, respectively; and, finally, specifications (6) and (7) add structural socioeconomic variables describing counties in 1930 to the OLS and 2SLS equations.

The OLS results suggest that New Deal spending on public works and relief or on the AAA played a trivial direct role in solidifying voters' support for the Democratic party over the long term. But our worry that an OLS estimate would be biased downward is clearly borne out as we move to a 2SLS setting (column 2). The OLS coefficient of the AAA variable has a negative sign, suggesting that the AAA spending harmed future Democratic election prospects, but the coefficient is statistically significant at only the 10 percent level and very small in magnitude. The OLS coefficient of public works and relief spending is positive but very small and statistically insignificant.

The use of instrumental variables, however, leads to a much stronger effect of New Deal public works and relief spending while changing the impact of the AAA very little. The public works and relief 2SLS coefficient of 0.0315 in column (2) of Table 1 is statistically significant and economically meaningful. The 2SLS public works and relief coefficient increases in size 
and remains statistically significant when all of the additional correlates are added to the analysis in column (7) of Table 1 . The coefficient of 0.0362 suggests that increasing a county's per capita relief and public works spending from $\$ 0$ to the sample mean level of \$277 would have caused the Democrats to have increased their support in that county by 10 percentage points over the long-term.

Column (3) presents OLS results when just the election-over-election marginal vote changes and state fixed effects are included as explanatory variables. The short-term shifts in Democratic voting between 1932 and 1936 and between 1936 and 1940 were related strongly to the long-term shift in Democratic voting. Moreover, as shown in columns (4) through (7), the marginal effects of the election-over-election vote shifts had effects on long-term voting that were independent of the one related to New Deal spending. When both sets of variables are included in the 2SLS estimation (column 7), the statistically significant effects of New Deal relief spending and the marginal vote changes remain.

The results in column (7) show that a 1 percentage point shift in the share voting for Roosevelt between 1932 and 1936 statistically significantly translated into a 0.34 percentage point increase in Democratic support over the long-term. Similarly, a 1 percentage point shift in the Democratic vote share from 1936 to 1940 contributed a statistically significantly 0.39 percentage point increase in long-term Democratic voting.

In contrast, the results show very weak long-run effects of the vote swing toward Roosevelt between the 1928 and 1932 elections. This finding suggests that Roosevelt's landslide victory in 1932 was driven more by voters casting ballots against Hoover, possibly punishing him for the weak economy, than they were voting for Roosevelt. Instead, it was Roosevelt's 
ability to win or maintain electoral support between 1932 and 1936 and between 1936 and 1940 that had the strongest persistent effect.

Finally, there were clear structural voting changes that took place after the 1932 election. The results in columns (6) and (7) in Table 1 show that many socioeconomic shifts favored the Democrats. Manufacturing workers, the foreign born, and counties with a greater share of tenant farmers all shifted statistically significantly toward Democrats after the 1932 critical election. Meanwhile, counties that were better off in 1930 tended to shift Republican. Specifically, counties with a greater share of tax returns filed, greater homeownership, and greater radio ownership in 1930 shifted away from Democrats. The statistically strong negative coefficient of the black population variable seems counter to conventional wisdom that black voters supported Democratic presidential candidates. The key to understanding this result is that counties with large black populations in 1930 were in the South, which voted overwhelmingly Democratic in the early 1930s. As white southern conservative voters began moving out of the Democratic and into the Republican party, a shift that was not consummated until the 1980s, the Democratic share of the southern vote fell. Black voters enfranchised by the Voting and Civil Rights Acts would not appear until elections later in the 1960s.

\section{Effects of New Deal Spending on Voting in 1936 and 1940}

There are a number of reasons why New Deal spending might not have been directly correlated with Democratic voting in the 1930s. First, the South was solidly Democratic and had been since the late $19^{\text {th }}$ century. There was little that Roosevelt and the New Dealers could gain from making large grants to the South and trying to incrementally increase the Democratic voting share; they were going to win those states in any case. In addition, southern Democrats 
often opposed increasing spending for relief and public works projects in the South that might have made black citizens more independent of white political patronage (Alston and Ferrie 1999). As a result, per capita New Deal spending in the South was lower than any other region of the country despite the fact that the Democratic share of the vote was higher than in any region of the country (see, e.g., Arrington 1970, Reading 1973, Wright 1974).

Democrats had a strategic reason to channel spending toward states where a small shift in voters' decisions could shift a county, state, or region from the Republican to Democratic column. This strategic spending dovetailed, in part, with New Deal efforts to relieve the unemployed who were concentrated in urban industrial areas. The states in the belt running west from New York to Illinois (what would become the "rust belt" in the 1970s) were heavily industrialized and had been the states where Democrats and Republicans closely contested elections in the late $19^{\text {th }}$ century and early $20^{\text {th }}$ century.

As one might expect, the impact of New Deal spending on electoral outcomes in the 1930s is much stronger when the IV analysis is performed. Table 2 shows the results from OLS and 2SLS estimations including and excluding various economic and socioeconomic controls. All of the equations are run as quasi-first differences in the sense that Roosevelt's 1932 vote share is included as a control variable so the coefficients represent the marginal impact of the New Deal variables on the 1936 vote relative to the 1932 outcome in each respective county. All of the equations include state fixed effects and standard errors are clustered at the state level. In Table 2 the coefficients of the New Deal spending variables are always positive. In each comparison of 2SLS coefficients and OLS coefficients with the same set of correlates, the 2SLS coefficients are always larger than the OLS coefficients, for both the AAA and the public works and relief variables. The OLS and 2SLS coefficients on AAA spending are not much 
different, but the coefficients on the relief and public works spending are 30 to 40 times bigger in the IV than in the OLS. In discussing the magnitudes of the coefficients, we focus on the 2SLS estimates with all correlates in specification (6) of Table 2 to minimize the impact of omitted variable bias. Increasing the relief and public works spending in a county from zero to an amount equal to the sample mean of $\$ 145$ would have increased Roosevelt's share of the vote by 5.4 percentage points relative to his 1932 landslide performance against Herbert Hoover. An increase in AAA spending from zero to the sample mean $(\$ 101)$ would have increased the Roosevelt vote share by a more modest 0.8 percentage point. The smaller AAA effect is consistent with the contrasting positive effects of the AAA for farm owners versus the negative effects for farm workers, sharecroppers, and tenants who were forced to move down or off the agricultural tenure ladder. The net effect is likely positive because the farm owners and those who kept their positions on the tenure ladder were likely to be voters, while the losers from the AAA were more likely to be disenfranchised.

It also appears that the long-run effects of New Deal spending on presidential voting were concentrated in the years from 1933 to 1936 . Table 3 presents the results for the 1940 election and the columns report both OLS and 2SLS results, using New Deal spending measured for different time periods, and the results using various sets of control variables. The first two columns present OLS and 2SLS estimates of Roosevelt's vote share in 1940 using New Deal spending from 1937 to 1939 (the last year for which we have county-level data). The only other controls are Roosevelt's vote share in 1932 and state fixed effects. We control for the 1932 election returns because, as we showed above, the New Deal had an impact on the 1936 election results so including 1936 would potentially dampen the true effect of the New Deal. Columns (3) 
and (4) add structural socioeconomic variables to the equation using the 1937 to 1939 spending data, and columns (5) and (6) add contemporaneous economic variables to them.

The central difference between New Deal spending before and after 1936 is the degree to which state governments determined the level of New Deal grant allocations to counties within the states. Before 1936, most relief funds were allocated by the Federal Emergency Relief Administration (FERA). FERA funds legally became the property of the states when they were granted and the federal relief administration had difficulty controlling the administration and allocation of relief funds within the states. In 1936 and after, the largest relief program was the Works Progress Administration (WPA). The federal government had much more direct control over the allocation of WPA funds than FERA funds. As Wallis, Fishback, and Kantor (2006) show, the allocation of WPA funds was significantly more responsive to economic factors like unemployment and lower incomes than FERA allocations, and significantly less likely to be influenced by political factors. In light of the difference in pre- and post- 1936 methods of allocating funds, it is not surprising that the effect of New Deal spending on voting behavior was different in the two periods.

As was the case in the 1936 voting model, the 2SLS coefficient of the relief and public works variable is larger than the OLS estimate. Not surprisingly, the coefficient on the 1937 to 1939 spending on the 1940 vote is smaller than in the 1936 analysis and is not statistically significant in 2SLS specifications (4) and (6) when additional correlates are added. If a county were to receive an average amount of New Deal relief and public works spending in the 1937 to 1939 period (\$132 per capita), then Roosevelt's vote share in 1940 would have increased by 2.6 percentage points $(132 \times 0.0196)$ relative to 1932 . The AAA coefficients for the 1940 voting in Table 3 are even smaller than the modest effects found for the 1936 votes in Table 2 . Thus, the 
main effect of the New Deal had become manifest by 1936 and New Deal spending after 1936 seems to have had only marginal effect on Roosevelt's electoral support after $1936 .{ }^{15}$ When paired with our long-term results in Table 1, it appears that it was early New Deal relief and public works spending that had an electoral impact that had lasting consequences.

New Deal public works and relief grants influenced long-term Democratic voting both directly and indirectly. The direct effect operates through the coefficient of public works and relief in specification (7) of Table 1, where we showed that a rise from no spending to the mean of \$277 over the span of the New Deal raised the share voting Democrat in the 1952-1960 elections, relative to pre-New Deal elections, by 10 percentage points. The indirect effect of New Deal spending operated through the share voting for Roosevelt between 1932 and 1936, since that change in vote share contributed to greater support of Democrats over the long-term. Based on the coefficient from specification (6) in Table 2, increasing the relief and public works spending in a county from zero to an amount equal to the sample mean of $\$ 145$ would have increased Roosevelt's share of the vote by 5.4 percentage points in 1936 relative to his 1932 landslide performance against Herbert Hoover. After multiplying this change by the coefficient of 0.3445 for the change in the vote from 1932 to 1936 from Table 1 specification (7), the indirect effect adds another 1.9 percent to the long-term support for Democratic presidential

${ }^{15}$ This statement is supported further by regressions in which we estimated the impact of New Deal spending after 1936 on voting in 1940, while holding constant Roosevelt's vote share in 1936. Those regressions, which are available from the authors, show very small effects of the New Deal spending.

Moreover, we experimented with including New Deal spending variables that covered the entire period from 1933 to 1939 rather than the period since the 1936 election. In results available from the authors, the AAA coefficient is effectively zero. Meanwhile, the 2SLS coefficient of public works and relief grant from 1933 to 1939 is positive and statistically insignificant. An increase in per capita relief and public works spending from zero to the mean of $\$ 277$ over the entire span of the New Deal would have translated into a 2.4 percentage point boost in Roosevelt's 1940 vote share $(277$ x 0.0088). Thus, the main effect of the New Deal had become manifest by 1936 and New Deal spending, broadly speaking, had only marginal effects on Roosevelt's electoral support after 1936. 
candidates. A similar procedure using the coefficients from Tables 1 and 3 suggests that the public works and relief spending had an indirect effect through the change in the vote for Roosevelt from 1936 to 1940 would have added an additional 0.6 percentage points in support for Democrat. As a result the combined direct and indirect effects may have been as large as 12 to 12.5 percent.

Finally, Table 4 reports the estimated coefficients of the structural and contemporaneous economic variables from specifications (5) and (6) for the 1936 regressions in Table 2 and the 1940 regressions in Table 3. The results of the contemporaneous economic variables do not indicate that Roosevelt particularly benefited or suffered as a result of economic fluctuations at the local level. One strong effect, though, is that counties with greater per capita retail sales growth in the inter-election period were more likely to side with Roosevelt in the 1936 election, holding support in 1932 constant. Generally speaking, however, we find little evidence that negative climate shocks in the form of the droughts, extreme wetness, or the horrors of the Dust Bowl were tied to Roosevelt.

The variables measuring the structural socioeconomic characteristics of the counties showed that Roosevelt picked up support in 1936 and 1940, relative to 1932, from counties with larger black populations, more urban residents, more manufacturing workers, and a larger share of foreign-born residents (in 1936). Support was lower in counties with greater religious participation (in 1940), greater homeownership, and in counties with a larger fraction of their land in farms. 


\section{Conclusions}

The New Deal programs that most directly affected the lives of unemployed Americans during the Great Depression were the emergency spending and public works programs, such as the FERA, CWA, WPA, PRA, PWA, and the farm programs. The New Deal distributed large sums of money to state and local governments to provide employment and relief and to build a wide array of public works. The New Deal paid farmers to change their production patterns in an attempt to raise commodity prices. Nearly all of these grants represented a substantial and novel change in the federal government's role in the economy, especially local economies. Recent studies have shown that the public works and relief programs had salutary effects in raising personal incomes and retail purchases, and contributed to a reduction in crime and several types of death rates. The AAA farm programs aided farm owners, but reduced economic opportunities for share tenants, sharecroppers, and unskilled farm workers. ${ }^{16}$

Was Roosevelt rewarded for his efforts to improve economic conditions? Yes. Drawing together the implications of our long- and short-term analyses of voter support for Democratic presidential candidates paints the following picture. The election of 1932 reflected an adverse judgment on Herbert Hoover rather than a permanent shift in voting patterns towards the

Democrats. In contrast, the shift in or retention of Democratic votes between the 1932 and 1936 and the 1936 and 1940 elections helped to secure a permanent change in the electorate that lasted into the 1960s. New Deal policies could not have affected the 1932 vote, but our results show that the change in voter behavior between 1932 and 1936 was a direct response to the New Deal. Our results suggest that an average increase in New Deal relief and public works spending resulted in a 5.4 percentage point increase in the 1936 Democratic voting share, and a smaller

${ }^{16}$ See Fishback, Horrace, and Kantor (2005, 2006), Fishback, Haines, and Kantor (2007), Fishback, Johnson, and Kantor (2010), Fishback and Kachanovskaya (2011), Barreca, Fishback and Kantor (2012), and Depew, Fishback, and Rhode (2012). 
amount in 1940. Given that an average amount of New Deal relief spending would have increased long-term Democratic support by 10 percentage points, it appears that Roosevelt's early, decisive actions created long-lasting positive benefits for the Democratic party. However, the effects of AAA spending were minimal because support from the farmers who benefitted was partially offset by opposition from those who saw their opportunities decline. Finally, on net, between 1936 and 1940 additional spending on public works and relief and the AAA added little to the support Roosevelt had already gained by 1936 .

Why didn't New Deal activity after 1936 sway voters much? Roosevelt was elected in 1932 with the hope and promise of providing "relief, recovery, and reform" to an ailing economy. People were out of work, losing homes, struggling to subsist, Roosevelt brought solutions and his administration's performance in its first 100 days was legendary. The economy was clearly improving from 1933 through 1937, although a double-dip recession in 1938 set the economy back and no doubt caused concern for citizens expecting an end to their economic frustration. Table 5 shows the unemployment figures throughout the 1930s. While unemployment had fallen to 9.1 percent by 1937 (counting emergency federal workers as employed), by 1938 it had jumped to 12.5 percent and only dropped significantly once the nation was set on a wartime buildup. Farmers also had reason to be concerned as prices that they received for their products languished in the latter part of the 1930s (see Table 5), something that the AAA was expected to reverse. Therefore, the New Deal offers cautionary lessons for politicians who offer high-profile policies, for which they expect admiration (see opening Obama quotation), designed to target specific economic problems. Voters are willing to reward policymakers when their efforts bear fruit, but when economic distress lingers, these same programs serve as a glaring reminder to voters that the incumbent has failed to bring the 
solutions promised. Yet, as the Democrats' electoral success in the post-1932 Realignment period shows, voters have the capacity to eagerly look beyond arguably unproductive policy interventions. In the end, it seems it was the New Deal effort that seemed to matter in voters' minds, not the end result. 


\section{REFERENCES}

Alston, L. J., 1981. Tenure choice in southern agriculture. Explorations in Economic History 18 (3), 211-32.

Alston, L. J., Ferrie, J., 1999. Southern Paternalism and the American Welfare State. Cambridge University Press, New York.

Arrington, L. J., 1970. Western agriculture and the New Deal. Agricultural History 49 (4), 337 53.

Barreca, A. I., Fishback, P.V., Kantor, S. (2012), Agricultural policy, migration, and malaria in the United States in the 1930s. Explorations in Economic History 49 (4), 381-98.

Biles, R., 1994. The South and the New Deal. University of Kentucky Press, Lexington, KY.

Clarke, J. N., 1996. Roosevelt's Warrior: Harold L. Ickes and the New Deal. Johns Hopkins University Press, Baltimore.

Depew, B., Fishback, P. and Rhode, P., 2012. New Deal or No Deal in the Cotton South: The Effect of the AAA on the Labor Structure in Agriculture. Working paper, University of Arizona.

Fishback, P.V., Haines. M.R., and Kantor, S., 2007. Births, deaths, and New Deal relief during the Great Depression. Review of Economics and Statistics 89 (1), 1-14.

Fishback, P.V., Horrace, W. C., Kantor, S., 2005. Did New Deal grant programs stimulate local economies? A study of federal grants and retail sales during the Great Depression. The Journal of Economic History 65 (1), 36-71.

, 2006. The impact of New Deal expenditures on mobility during the Great Depression. Explorations in Economic History 43 (2), 179-222.

Fishback, P. V., Johnson, R. S., Kantor, S., 2010. Striking at the roots of crime: The impact of social welfare spending on crime during the Great Depression. Journal of Law and Economics 53 (4), 715-40.

Fishback, P. V., Kachanovskaya, V., 2011. In search of the multiplier for federal spending in the states during the Great Depression. National Bureau of Economic Research Working Paper No. 16561.

Fishback, P. V., Kantor, S., Wallis, J. J., 2003. Can the New Deal's three R's be rehabilitated? A program-by-program, county-by-county analysis. Explorations in Economic History 40 (3), 278-307.

Frankel, J.A., Romer, D., 1999. Does trade cause growth? American Economic Review 89 (3), 379-99.

Hansen, Z. K., Libecap, G. D., 2004. Small farms, externalities, and the Dust Bowl of the 1930s. Journal of Political Economy 112 (3), 665-94.

Hoxby, C.M., 2000. Does competition among public schools benefit students and taxpayers? American Economic Review 90 (5), 1209-38.

Levitt, S. D., Snyder, J. M., Jr., 1997. The impact of federal spending on House election outcomes. Journal of Political Economy 105 (1), 30-53.

Reading, D. C., 1973. New Deal activity and the states, 1933 to 1939. Journal of Economic History 33 (4), 792-810.

Romer, C. D., 1992. What ended the Great Depression? The Journal of Economic History 52 (4), $757-84$.

Saloutos, T., 1982. The American Farmer and the New Deal. Iowa State University Press, Ames, IA. 
Schlesinger, A., Jr., 1958. The Age of Roosevelt: The Coming of the New Deal. HoughtonMifflin, Boston.

U.S. Census Bureau, 1975. Historical Statistics of the United States: From Colonial Times to 1970. Government Printing Office, Washington, DC.

Wallis, J. J., 1984. The birth of the old federalism: Financing the New Deal, 1932-1940. Journal of Economic History 44 (1), 139-59. , 1985. Why 1933? The origins and timing of national government growth, 1933-1940. Research in Economic History 4, 1-51.

Wallis, J.J., Fishback, P.V., Kantor, S., 2006. Politics, relief, and reform: Roosevelt's efforts to control corruption and manipulation during the New Deal. In: E. Glaeser, C. Goldin, Corruption and Reform. University of Chicago Press, Chicago.

Whatley, W. C., 1983. Labor for the picking: The New Deal in the South. Journal of Economic History 43 (4), 905-29.

Wright, G., 1974. The political economy of New Deal spending: An econometric analysis. Review of Economics and Statistics 56 (1), 30-38. 
Table 1

OLS and 2SLS Estimates of Long-Difference Change in Democratic Support, 1896-1960

\begin{tabular}{|c|c|c|c|c|c|c|c|c|}
\hline Variables & $\begin{array}{l}\text { Mean } \\
\text { (std. } \\
\text { dev.) }\end{array}$ & $\begin{array}{l}\text { (1) } \\
\text { OLS }\end{array}$ & $\begin{array}{c}(2) \\
2 S L S\end{array}$ & $\begin{array}{l}\text { (3) } \\
\text { OLS }\end{array}$ & $\begin{array}{l}\text { (4) } \\
\text { OLS }\end{array}$ & $\begin{array}{c}(5) \\
2 S L S\end{array}$ & $\begin{array}{l}\text { (6) } \\
\text { OLS }\end{array}$ & $\begin{array}{l}(7) \\
2 S L S\end{array}$ \\
\hline $\begin{array}{l}\text { Dependent variable: } \\
\text { Long-difference in Democratic vote }{ }^{1}\end{array}$ & $\begin{array}{l}-5.234 \\
(18.56)\end{array}$ & & & & & & & \\
\hline \multicolumn{9}{|l|}{ Independent variables: } \\
\hline Constant & & $\begin{array}{l}-5.554 \\
(-11.0)\end{array}$ & $\begin{array}{l}-2.089 \\
(-0.50)\end{array}$ & $\begin{array}{l}-3.086 \\
(-1.88)\end{array}$ & $\begin{array}{l}-3.569 \\
(-2.27)\end{array}$ & $\begin{array}{l}-3.250 \\
(-0.80)\end{array}$ & $\begin{array}{l}9.019 \\
(2.00)\end{array}$ & $\begin{array}{l}-8.763 \\
(-0.77)\end{array}$ \\
\hline $\begin{array}{l}\text { Per capita AAA spending. 1933- } \\
1939\end{array}$ & $\begin{array}{r}155.7 \\
(249.9)\end{array}$ & $\begin{array}{r}-0.0026 \\
(-1.64)\end{array}$ & $\begin{array}{r}-0.0047 \\
(-1.77)\end{array}$ & & $\begin{array}{r}-0.0015 \\
(-0.68)\end{array}$ & $\begin{array}{r}-0.0038 \\
(-1.18)\end{array}$ & $\begin{array}{r}0.0003 \\
(0.18)\end{array}$ & $\begin{array}{r}-0.0018 \\
(-0.73)\end{array}$ \\
\hline $\begin{array}{l}\text { Per capita public works and relief } \\
\text { spending, 1933-1939 }\end{array}$ & $\begin{array}{r}277.1 \\
(259.6)\end{array}$ & $\begin{array}{r}0.0026 \\
(1.60)\end{array}$ & $\begin{array}{r}0.0315 \\
(2.09)\end{array}$ & & $\begin{array}{r}0.0018 \\
(1.60)\end{array}$ & $\begin{array}{r}0.0292 \\
(1.97)\end{array}$ & $\begin{array}{r}0.0012 \\
(1.56)\end{array}$ & $\begin{array}{r}0.0362 \\
(2.48)\end{array}$ \\
\hline$\Delta$ Democratic vote share $1932-1928$ & $\begin{array}{r}23.93 \\
(11.59)\end{array}$ & & & $\begin{array}{r}0.0425 \\
(0.48)\end{array}$ & $\begin{array}{r}0.0466 \\
(0.57)\end{array}$ & $\begin{array}{r}0.0389 \\
(0.52)\end{array}$ & $\begin{array}{r}0.0843 \\
(1.28)\end{array}$ & $\begin{array}{r}0.0817 \\
(1.14)\end{array}$ \\
\hline$\Delta$ Democratic vote share $1936-1932$ & $\begin{array}{l}-1.665 \\
(7.647)\end{array}$ & & & $\begin{array}{r}0.3517 \\
(3.44)\end{array}$ & $\begin{array}{r}0.3493 \\
(3.52)\end{array}$ & $\begin{array}{r}0.2937 \\
(3.01)\end{array}$ & $\begin{array}{r}0.3875 \\
(6.07)\end{array}$ & $\begin{array}{r}0.3445 \\
(5.19)\end{array}$ \\
\hline$\Delta$ Democratic vote share $1940-1936$ & $\begin{array}{l}-6.117 \\
(6.505)\end{array}$ & & & $\begin{array}{r}0.4217 \\
(2.95)\end{array}$ & $\begin{array}{r}0.4064 \\
(2.60)\end{array}$ & $\begin{array}{r}0.3498 \\
(2.37)\end{array}$ & $\begin{array}{r}0.3815 \\
(3.08)\end{array}$ & $\begin{array}{r}0.3884 \\
(3.10)\end{array}$ \\
\hline Pct. of population black, 1930 & $\begin{array}{r}11.19 \\
(18.44)\end{array}$ & & & & & & $\begin{array}{r}-0.2714 \\
(-3.41)\end{array}$ & $\begin{array}{r}-0.2491 \\
(-2.89)\end{array}$ \\
\hline $\begin{array}{l}\text { Pct. of population living in urban } \\
\text { area, } 1930\end{array}$ & $\begin{array}{r}20.46 \\
(24.42)\end{array}$ & & & & & & $\begin{array}{r}0.0204 \\
(1.58)\end{array}$ & $\begin{array}{r}0.0041 \\
(0.18)\end{array}$ \\
\hline $\begin{array}{l}\text { Pct. of population manufacturing } \\
\text { workers, } 1929\end{array}$ & $\begin{array}{r}4.582 \\
(5.034)\end{array}$ & & & & & & $\begin{array}{r}0.1329 \\
(1.42)\end{array}$ & $\begin{array}{r}0.1892 \\
(1.89)\end{array}$ \\
\hline Pct. of population foreign born, 1930 & $\begin{array}{r}4.663 \\
(5.804)\end{array}$ & & & & & & $\begin{array}{r}0.8676 \\
(7.43)\end{array}$ & $\begin{array}{r}0.8134 \\
(6.27)\end{array}$ \\
\hline Pct. of population illiterate, 1930 & $\begin{array}{r}5.197 \\
(5.520)\end{array}$ & & & & & & $\begin{array}{r}0.0651 \\
(0.50)\end{array}$ & $\begin{array}{r}0.1962 \\
(1.17)\end{array}$ \\
\hline $\begin{array}{l}\text { Pct. of population belonging to } \\
\text { religious organizations, } 1926\end{array}$ & $\begin{array}{r}45.68 \\
(18.19)\end{array}$ & & & & & & $\begin{array}{r}0.0272 \\
(1.12)\end{array}$ & $\begin{array}{r}0.0519 \\
(1.53)\end{array}$ \\
\hline Pct. of county's land in farms, 1929 & $\begin{array}{r}64.38 \\
(26.95)\end{array}$ & & & & & & $\begin{array}{r}-0.0153 \\
(-0.91)\end{array}$ & $\begin{array}{r}0.0528 \\
(1.37)\end{array}$ \\
\hline
\end{tabular}




\begin{tabular}{|c|c|c|c|c|c|c|c|c|}
\hline $\begin{array}{l}\text { Percentage of farm operated by } \\
\text { tenants, } 1929\end{array}$ & $\begin{array}{r}31.25 \\
(15.35)\end{array}$ & & & & & & $\begin{array}{r}0.1608 \\
(3.20)\end{array}$ & $\begin{array}{r}0.2055 \\
(3.45)\end{array}$ \\
\hline Percentage of households owning & 50.84 & & & & & & -0.0915 & -0.0735 \\
\hline homes, 1930 & $(12.22)$ & & & & & & $(-1.44)$ & $(-1.07)$ \\
\hline Percentage of households owning & 51.93 & & & & & & -0.2952 & -0.2492 \\
\hline radios, 1930 & $(18.38)$ & & & & & & $(-3.58)$ & $(-2.83)$ \\
\hline \multirow[t]{2}{*}{ Tax returns filed per capita } & 0.0171 & & & & & & -78.01 & -69.77 \\
\hline & $(0.0166)$ & & & & & & $(-2.88)$ & $(-1.86)$ \\
\hline State fixed effects & & Yes & Yes & Yes & Yes & Yes & Yes & Yes \\
\hline F-statistic: Excluded instruments in & & & 16.1 & & & 15.9 & & 13.3 \\
\hline AAA equation (p-value) & & & $(0.000)$ & & & $(0.000)$ & & $(0.000)$ \\
\hline F-statistic: Excluded instruments in & & & 10.5 & & & 9.88 & & 7.63 \\
\hline $\begin{array}{l}\text { relief \& public works equation (p- } \\
\text { value) }\end{array}$ & & & $(0.000)$ & & & $(0.000)$ & & $(0.001)$ \\
\hline $\mathrm{R}^{2}$ & & 0.74 & 0.63 & 0.76 & 0.76 & & 0.81 & \\
\hline Adjusted $\mathrm{R}^{2}$ & & 0.74 & & 0.76 & 0.76 & 0.66 & 0.80 & 0.65 \\
\hline $\mathrm{N}$ & 2,901 & 2,901 & 2,901 & 2,901 & 2,901 & 2,901 & 2,901 & 2,901 \\
\hline
\end{tabular}

Notes \& sources: ${ }^{1}$ The dependent variable is the long-difference between the average vote for the Democratic presidential candidate in 1952 , 1956, and 1960, and the average vote for the Democratic presidential candidates from 1896 to 1928, inclusive. Standard errors are clustered at the state level. See data appendix in Fishback, Horrace, and Kantor (2005) for sources. Presidential voting in 1952, 1956, and 1960 was collected from ICPSR file number 8611. 
Table 2

OLS and 2SLS Estimates of Roosevelt's Percentage of the Vote, 1936

\begin{tabular}{|c|c|c|c|c|c|c|c|}
\hline Variables & $\begin{array}{r}\text { Mean } \\
\text { (std. } \\
\text { dev.) }\end{array}$ & $\begin{array}{r}(1) \\
\text { OLS }\end{array}$ & $\begin{array}{r}(2) \\
2 S L S\end{array}$ & $\begin{array}{r}(3) \\
\text { OLS }\end{array}$ & $\begin{array}{r}(4) \\
2 S L S\end{array}$ & $\begin{array}{r}(5) \\
\text { OLS }\end{array}$ & $\begin{array}{r}(6) \\
2 S L S\end{array}$ \\
\hline \multicolumn{8}{|l|}{ Dependent variable: } \\
\hline Roosevelt vote share, 1936 & $\begin{array}{r}66.22 \\
(18.12)\end{array}$ & & & & & & \\
\hline \multicolumn{8}{|l|}{ Independent variables: } \\
\hline Constant & & $\begin{array}{r}7.082 \\
(2.51)\end{array}$ & $\begin{array}{r}4.414 \\
(0.94)\end{array}$ & $\begin{array}{r}13.42 \\
(3.39)\end{array}$ & $\begin{array}{r}3.236 \\
(0.67)\end{array}$ & $\begin{array}{l}-9.719 \\
(-0.37)\end{array}$ & $\begin{array}{r}-63.7 \\
(-1.45)\end{array}$ \\
\hline Per capita AAA spending, 1933-1936 & $\begin{array}{r}100.9 \\
(171.7)\end{array}$ & $\begin{array}{r}0.0016 \\
(1.06)\end{array}$ & $\begin{array}{r}0.0040 \\
(1.41)\end{array}$ & $\begin{array}{r}0.0061 \\
(6.98)\end{array}$ & $\begin{array}{r}0.0072 \\
(4.41)\end{array}$ & $\begin{array}{r}0.0062 \\
(6.40)\end{array}$ & $\begin{array}{r}0.0076 \\
(2.98)\end{array}$ \\
\hline $\begin{array}{l}\text { Per capita public works and relief spending, } \\
1933-1936\end{array}$ & $\begin{array}{r}145.1 \\
(169.4)\end{array}$ & $\begin{array}{r}0.0015 \\
(1.02)\end{array}$ & $\begin{array}{r}0.0661 \\
(2.41)\end{array}$ & $\begin{array}{r}0.0010 \\
(0.93)\end{array}$ & $\begin{array}{r}0.0282 \\
(2.06)\end{array}$ & $\begin{array}{r}0.0010 \\
(0.74)\end{array}$ & $\begin{array}{r}0.0369 \\
(2.16)\end{array}$ \\
\hline Roosevelt's share of the vote in 1932 & $\begin{array}{r}67.89 \\
(18.21)\end{array}$ & $\begin{array}{r}0.8656 \\
(20.8)\end{array}$ & $\begin{array}{r}0.8530 \\
(17.9)\end{array}$ & $\begin{array}{r}0.8177 \\
(22.1)\end{array}$ & $\begin{array}{r}0.7939 \\
(20.0)\end{array}$ & $\begin{array}{r}0.8160 \\
(22.3)\end{array}$ & $\begin{array}{r}0.7874 \\
(18.4)\end{array}$ \\
\hline Contemporaneous Economic Variables: & & No & No & No & No & Yes & Yes \\
\hline Structural Socioeconomic Variables: & & No & No & Yes & Yes & Yes & Yes \\
\hline State Fixed Effects & & Yes & Yes & Yes & Yes & Yes & Yes \\
\hline F-statistic: Excluded instruments in AAA & & & 18.8 & & 14.2 & & 25.2 \\
\hline equation (p-value) & & & $(0.000)$ & & $(0.000)$ & & $(0.000)$ \\
\hline F-statistic: Excluded instruments in relief \& & & & 6.92 & & 6.74 & & 5.69 \\
\hline public works equation (p-value) & & & $(0.002)$ & & $(0.003)$ & & $(0.006)$ \\
\hline $\mathrm{R}^{2}$ & & 0.89 & 0.62 & 0.92 & 0.88 & 0.93 & 0.85 \\
\hline Adjusted $\mathrm{R}^{2}$ & & 0.89 & & 0.92 & & 0.93 & \\
\hline $\mathrm{N}$ & & 2,901 & 2,901 & 2,901 & 2,901 & 2,899 & 2,899 \\
\hline
\end{tabular}

Notes \& sources: The instrumental variables that are used are the number of rivers in county flowing through 21 or more counties and average farm size in 1929. State fixed effects are included in all models. t-statistics are in parentheses. Standard errors are clustered at the state level. See Table 4 for the coefficients to the Contemporary and Structural Socioeconomic variables from columns (5) and (6). See Table 1 for sources. 
Table 3

OLS and 2SLS Estimates of Roosevelt's Percentage of the Vote, 1940

\begin{tabular}{|c|c|c|c|c|c|c|c|}
\hline & $\begin{array}{r}\text { Mean } \\
\text { (std. dev.) } \\
\end{array}$ & $\begin{array}{r}(1) \\
\text { OLS }\end{array}$ & $\begin{array}{r}(2) \\
2 S L S \\
\end{array}$ & $\begin{array}{r}(3) \\
\text { OLS }\end{array}$ & $\begin{array}{r}(4) \\
2 S L S \\
\end{array}$ & $\begin{array}{r}(5) \\
\text { OLS }\end{array}$ & $\begin{array}{r}(6) \\
2 S L S \\
\end{array}$ \\
\hline $\begin{array}{l}\text { Dependent variable: } \\
\text { Roosevelt vote share, } 1940\end{array}$ & $\begin{array}{r}60.09 \\
(20.46)\end{array}$ & & & & & & \\
\hline Constant & & $\begin{array}{c}4.273 \\
(1.20)\end{array}$ & $\begin{array}{c}8.226 \\
(1.51)\end{array}$ & $\begin{array}{r}12.89 \\
(2.26)\end{array}$ & $\begin{array}{c}10.45 \\
(1.59)\end{array}$ & $\begin{array}{l}-46.26 \\
(-1.35)\end{array}$ & $\begin{array}{l}-55.92 \\
(-1.73)\end{array}$ \\
\hline $\begin{array}{l}\text { Per capita AAA spending, 1937- } \\
1939\end{array}$ & $\begin{array}{r}54.82 \\
(89.12)\end{array}$ & $\begin{array}{r}-0.0048 \\
(-1.06)\end{array}$ & $\begin{array}{r}-0.0014 \\
(-0.327\end{array}$ & $\begin{array}{r}0.0022 \\
(1.42)\end{array}$ & $\begin{array}{r}0.0005 \\
(0.13)\end{array}$ & $\begin{array}{r}0.0040 \\
(2.44)\end{array}$ & $\begin{array}{r}0.0016 \\
(0.24)\end{array}$ \\
\hline $\begin{array}{l}\text { Per capita public works and relief } \\
\text { spending, 1937-1939 }\end{array}$ & $\begin{array}{r}132.0 \\
(105.6)\end{array}$ & $\begin{array}{r}0.0079 \\
(2.14)\end{array}$ & $\begin{array}{r}0.0446 \\
(1.40)\end{array}$ & $\begin{array}{r}0.0048 \\
(2.08)\end{array}$ & $\begin{array}{r}0.0144 \\
(0.78)\end{array}$ & $\begin{array}{r}0.0056 \\
(2.67)\end{array}$ & $\begin{array}{r}0.0196 \\
(0.92)\end{array}$ \\
\hline $\begin{array}{l}\text { Roosevelt's share of the vote in } \\
1932\end{array}$ & $\begin{array}{r}67.89 \\
(18.21)\end{array}$ & $\begin{array}{r}0.8106 \\
(15.2)\end{array}$ & $\begin{array}{r}0.8109 \\
(15.2)\end{array}$ & $\begin{array}{r}0.7901 \\
(15.8)\end{array}$ & $\begin{array}{r}0.7868 \\
(14.5)\end{array}$ & $\begin{array}{r}0.7896 \\
(15.7)\end{array}$ & $\begin{array}{r}0.7848 \\
(15.3)\end{array}$ \\
\hline $\begin{array}{l}\text { Contemporaneous Economic } \\
\text { Variables } \\
\text { Structural Socioeconomic }\end{array}$ & & No & No & No & No & Yes & Yes \\
\hline $\begin{array}{l}\text { Variables } \\
\text { State Fixed Effects }\end{array}$ & & $\begin{array}{r}\text { No } \\
\text { Yes }\end{array}$ & $\begin{array}{r}\text { No } \\
\text { Yes }\end{array}$ & $\begin{array}{l}\text { Yes } \\
\text { Yes }\end{array}$ & $\begin{array}{l}\text { Yes } \\
\text { Yes }\end{array}$ & $\begin{array}{l}\text { Yes } \\
\text { Yes }\end{array}$ & $\begin{array}{l}\text { Yes } \\
\text { Yes }\end{array}$ \\
\hline $\begin{array}{l}\text { F-statistic: Excluded instruments } \\
\text { in AAA equation ( } p \text {-value) }\end{array}$ & & & $\begin{array}{r}7.08 \\
(0.002)\end{array}$ & & $\begin{array}{r}8.22 \\
(0.001)\end{array}$ & & $\begin{array}{r}6.07 \\
(0.005)\end{array}$ \\
\hline $\begin{array}{l}\text { F-statistic: Excluded instruments } \\
\text { in relief \& public works equation } \\
\text { (p-value) }\end{array}$ & & & $\begin{array}{r}12.6 \\
(0.000)\end{array}$ & & $\begin{array}{r}6.98 \\
(0.002)\end{array}$ & & $\begin{array}{r}6.61 \\
(0.003)\end{array}$ \\
\hline $\mathrm{R}^{2}$ & & 0.88 & 0.85 & 0.90 & 0.90 & 0.90 & 0.90 \\
\hline Adjusted $\mathrm{R}^{2}$ & & 0.88 & & 0.90 & & 0.90 & \\
\hline $\mathrm{N}$ & & 2,901 & 2,901 & 2,901 & 2,901 & 2,899 & 2,899 \\
\hline
\end{tabular}

Notes \& sources: The instrumental variables that are used are the number of rivers in county flowing through 21 or more counties and average farm size in 1929. State fixed effects are included in all models. t-statistics are in parentheses. Standard errors are clustered at the state level. See Table 4 for the coefficients to the Contemporary and Structural Socioeconomic variables from columns (6) and (6). See Table 1 for sources. 
Table 4

Coefficients of Contemporaneous Economic and Structural Socioeconomic Variables from 1936 and 1940 OLS and 2SLS Regressions

\begin{tabular}{|c|c|c|c|c|c|c|}
\hline & \multicolumn{3}{|c|}{ Table 2 (1936) } & \multicolumn{3}{|c|}{ Table 3 (1940) } \\
\hline & $\begin{array}{r}\text { Mean } \\
\text { (std. } \\
\text { dev.) }\end{array}$ & (5) & (6) & $\begin{array}{r}\text { Mean } \\
\text { (std. } \\
\text { dev.) }\end{array}$ & (5) & (6) \\
\hline Contemporaneous Economic Variables & & & & & & \\
\hline $\begin{array}{l}\text { Percentage change in real per capita retail } \\
\text { sales } 1933-1935 \text { or } 1935-1939\end{array}$ & $\begin{array}{r}0.2477 \\
(0.1804)\end{array}$ & $\begin{array}{r}2.533 \\
(3.26)\end{array}$ & $\begin{array}{r}2.202 \\
(2.32)\end{array}$ & $\begin{array}{r}0.2044 \\
(0.1812)\end{array}$ & $\begin{array}{r}1.156 \\
(1.01)\end{array}$ & $\begin{array}{r}1.080 \\
(0.97)\end{array}$ \\
\hline Real per capita retail sales, 1935 or 1939 & $\begin{array}{r}435.1 \\
(228.7)\end{array}$ & $\begin{array}{r}0.0044 \\
(3.36)\end{array}$ & $\begin{array}{r}0.0045 \\
(1.25)\end{array}$ & $\begin{array}{r}530.7 \\
(273.0)\end{array}$ & $\begin{array}{r}-0.0007 \\
(-0.36)\end{array}$ & $\begin{array}{r}-0.0004 \\
(-0.18)\end{array}$ \\
\hline $\begin{array}{l}\text { Months of excess or severe drought, 1933- } \\
1936 \text { or } 1937-1940\end{array}$ & $\begin{array}{r}11.87 \\
(10.33)\end{array}$ & $\begin{array}{r}-0.0171 \\
(-0.58)\end{array}$ & $\begin{array}{r}-0.0487 \\
(-1.34)\end{array}$ & $\begin{array}{r}6.979 \\
(10.56)\end{array}$ & $\begin{array}{r}-0.0643 \\
(-0.94)\end{array}$ & $\begin{array}{r}-0.0654 \\
(-0.95)\end{array}$ \\
\hline $\begin{array}{l}\text { Months of excess or severe wetness, } 1933- \\
1936 \text { or } 1937-1940\end{array}$ & $\begin{array}{r}1.194 \\
(2.508)\end{array}$ & $\begin{array}{r}0.0225 \\
(0.41)\end{array}$ & $\begin{array}{r}-0.2810 \\
(-1.10)\end{array}$ & $\begin{array}{r}1.353 \\
(2.583)\end{array}$ & $\begin{array}{r}-0.1190 \\
(-1.30)\end{array}$ & $\begin{array}{r}-0.1828 \\
(-1.38)\end{array}$ \\
\hline $\begin{array}{l}\text { Average monthly temperature, } 1933-1936 \\
\text { or } 1937-1940 \text { relative to } 1920 \text { s average }\end{array}$ & $\begin{array}{r}1.014 \\
(0.0168)\end{array}$ & $\begin{array}{r}20.61 \\
(0.81)\end{array}$ & $\begin{array}{r}62.40 \\
(1.46)\end{array}$ & $\begin{array}{r}1.008 \\
(0.0140)\end{array}$ & $\begin{array}{r}59.21 \\
(1.71)\end{array}$ & $\begin{array}{r}66.99 \\
(1.94)\end{array}$ \\
\hline "Dustbowl" County & $\begin{array}{r}0.0203 \\
(0.1348)\end{array}$ & $\begin{array}{r}-0.7844 \\
(-0.82)\end{array}$ & $\begin{array}{l}-3.683 \\
(-1.66)\end{array}$ & $\begin{array}{r}0.0203 \\
(0.1348)\end{array}$ & $\begin{array}{l}-2.200 \\
(-2.28)\end{array}$ & $\begin{array}{l}-1.681 \\
(-0.70)\end{array}$ \\
\hline Structural Socioeconomic Variables: & & & & & & \\
\hline Pct. of population black, 1930 & $\begin{array}{r}11.20 \\
(18.44)\end{array}$ & $\begin{array}{r}0.1209 \\
(4.83)\end{array}$ & $\begin{array}{r}0.1249 \\
(4.72)\end{array}$ & $\begin{array}{r}11.20 \\
(18.44)\end{array}$ & $\begin{array}{r}0.0820 \\
(3.52)\end{array}$ & $\begin{array}{r}0.0876 \\
(3.47)\end{array}$ \\
\hline $\begin{array}{l}\text { Pct. of population living in urban area, } \\
1930\end{array}$ & $\begin{array}{r}20.47 \\
(24.42)\end{array}$ & $\begin{array}{r}0.0482 \\
(5.97)\end{array}$ & $\begin{array}{r}0.0633 \\
(3.32)\end{array}$ & $\begin{array}{r}20.47 \\
(24.42)\end{array}$ & $\begin{array}{r}0.0538 \\
(3.49)\end{array}$ & $\begin{array}{r}0.0435 \\
(2.72)\end{array}$ \\
\hline $\begin{array}{l}\text { Pct. of population manufacturing workers, } \\
1929\end{array}$ & $\begin{array}{r}3.336 \\
(3.389)\end{array}$ & $\begin{array}{r}0.3353 \\
(6.48)\end{array}$ & $\begin{array}{r}0.3795 \\
(5.21)\end{array}$ & $\begin{array}{r}3.336 \\
(3.389)\end{array}$ & $\begin{array}{r}0.2104 \\
(4.39)\end{array}$ & $\begin{array}{r}0.2182 \\
(3.89)\end{array}$ \\
\hline Pct. of population foreign born, 1930 & $\begin{array}{r}4.664 \\
(5.805)\end{array}$ & $\begin{array}{r}0.3349 \\
(3.18)\end{array}$ & $\begin{array}{r}0.3202 \\
(2.73)\end{array}$ & $\begin{array}{r}4.664 \\
(5.805)\end{array}$ & $\begin{array}{r}0.1560 \\
(0.92)\end{array}$ & $\begin{array}{r}0.1428 \\
(0.93)\end{array}$ \\
\hline Pct. of population illiterate, 1930 & $\begin{array}{r}5.190 \\
(5.504)\end{array}$ & $\begin{array}{r}-0.0301 \\
(-0.51)\end{array}$ & $\begin{array}{r}0.0623 \\
(0.76)\end{array}$ & $\begin{array}{r}5.190 \\
(5.504)\end{array}$ & $\begin{array}{r}-0.0356 \\
(-0.51)\end{array}$ & $\begin{array}{r}-0.0048 \\
(-0.06)\end{array}$ \\
\hline $\begin{array}{l}\text { Pct. of population belonging to religious } \\
\text { organizations, } 1926\end{array}$ & $\begin{array}{r}45.70 \\
(18.17)\end{array}$ & $\begin{array}{r}-0.0174 \\
(-1.04)\end{array}$ & $\begin{array}{r}0.0082 \\
(0.30)\end{array}$ & $\begin{array}{r}45.70 \\
(18.17)\end{array}$ & $\begin{array}{r}-0.0374 \\
(-1.67)\end{array}$ & $\begin{array}{r}-0.0353 \\
(-1.63)\end{array}$ \\
\hline Pct. of county's land in farms, 1929 & $\begin{array}{r}64.39 \\
(26.93)\end{array}$ & $\begin{array}{r}-0.0346 \\
(-3.02)\end{array}$ & $\begin{array}{r}0.0040 \\
(0.71)\end{array}$ & $\begin{array}{r}64.39 \\
(26.93)\end{array}$ & $\begin{array}{r}-0.0615 \\
(-4.19)\end{array}$ & $\begin{array}{r}-0.0504 \\
(-2.29)\end{array}$ \\
\hline
\end{tabular}




\begin{tabular}{lrrr|rrr} 
Percentage of farm operated by tenants, & 31.73 & -0.0136 & 0.0113 & 31.73 & -0.0337 & -0.0243 \\
1929 & $(15.94)$ & $(-0.77)$ & $(0.56)$ & $(15.94)$ & $(-1.47)$ & $(-0.91)$ \\
Percentage of households owning homes, & 51.86 & -0.0961 & -0.0804 & 51.86 & -0.1380 & -0.1374 \\
1930 & $(12.99)$ & $(-3.23)$ & $(-2.15)$ & $(12.99)$ & $(-2.98)$ & $(-2.80)$ \\
Percentage of households owning radios, & 34.50 & 0.0144 & 0.0066 & 34.50 & 0.0518 & 0.0642 \\
1930 & $(17.65)$ & $(0.42)$ & $(0.17)$ & $(17.65)$ & $(1.06)$ & $(1.25)$ \\
Tax returns filed per capita & 0.0118 & -33.88 & -77.45 & 0.0118 & 25.66 & 28.80 \\
& $(0.0130)$ & $(-1.56)$ & $(-1.40)$ & $(0.0130)$ & $(0.94)$ & $(1.03)$ \\
\hline
\end{tabular}

Notes \& sources: The coefficients were drawn from the full regression of voting returns in the respective years and included the variables reported here and in Table 2 and 3. 
Table 5

Unemployment and Agricultural Prices

\begin{tabular}{lll}
\hline Year & Unemployment & $\begin{array}{l}\text { Prices received } \\
\text { by farmers } \\
\text { (191-1914=100) }\end{array}$ \\
\hline 1930 & 8.7 & 125 \\
1931 & 15.3 & 87 \\
1932 & 22.5 & 65 \\
1933 & 20.6 & 70 \\
1934 & 16.0 & 90 \\
1935 & 14.2 & 109 \\
1936 & 9.9 & 114 \\
1937 & 9.1 & 123 \\
1938 & 12.5 & 97 \\
1939 & 11.3 & 95 \\
1940 & 9.5 & 100 \\
\hline
\end{tabular}

Sources: Unemployment is from Darby $(1976,8)$ and reports his corrected BLS series. This figure includes emergency federal relief works as employed. Prices received by farmers are from the U.S. Census (1975), series Da1337. 